\title{
Bottom-up Populism: How Relative Deprivation and Populist Attitudes Mobilize Leaderless Anti-Government Protest
}

\author{
Adrian Lüders ${ }^{1,2}$, Karolina Urbanska ${ }^{3}$, Robin Wollast $^{2}$, Armelle Nugier ${ }^{2}$, Serge Guimond ${ }^{2}$ \\ [1] Centre for Social Issues Research, University of Limerick, Limerick, Ireland. [2] Laboratoire de Psychologie Sociale et Cognitive, Université Clermont Auvergne, \\ Clermont Ferrand, France. [3] Department of Psychology, University of Sheffield, Sheffield, United Kingdom.
}

Journal of Social and Political Psychology, 2021, Vol. 9(2), 506-519, https://doi.org/10.5964/jspp.7349

Received: 2020-09-05 • Accepted: 2021-08-15 • Published (VoR): 2021-10-18

Handling Editor: Maria Fernandes-Jesus, York St John University, York, United Kingdom

Corresponding Author: Adrian Lüders, Centre for Social Issues Research, Department of Psychology, Education and Health Sciences, University of Limerick, Limerick, Ireland. E-mail: Adrian.Lueders@ul.ie

Supplementary Materials: Data, Materials [see Index of Supplementary Materials]

\begin{abstract}
The present research focuses on populism as a bottom-up phenomenon that emerges from shared perceptions of relative deprivation. We predict that by serving as a shared ideological basis, populist attitudes can mobilize leaderless anti-government protest across ideological boundaries. We test this prediction in the context of the French Yellow Vests movement. Using a sample of French citizens $(\mathrm{N}=562)$, we compare the effects of different indicators of relative deprivation on Yellow Vest protest participation and the extent to which populist attitudes account for these relationships. Results indicate that protests were fuelled by indicators of relative deprivation at the individual and group levels. Populist attitudes were best predicted by vertical comparisons between "the people" and "the elite" and fully accounted for the relationship between this type of group relative deprivation and protesting. Conversely, populist attitudes only partially accounted for the relationships between protesting and traditional measures of relative deprivation that either contrast natives with immigrants or individuals with fellow citizens. The findings strengthen the understanding of populism as a "thin centred" belief set that can unite and mobilize those who feel unfairly disadvantaged compared to a socio-political elite.
\end{abstract}

\section{Keywords}

populism, populist attitudes, relative deprivation, protest, collective action, Yellow Vests, Gilets Jaunes, Emanuele Macron

\section{The Yellow Vests Movement}

The Yellow Vests (YV) movement started on November $17^{\text {th }}, 2018$, and quickly rose to become the most impactful protest movement in France since May 1968 (Mazeau, 2019). The early roots of the YV lay in an online petition calling for a cut in fuel prices that was then linked with another Facebook event calling for road blockades to protest against increasing expenses for car owners. At some point, the "Gilet Jaune", a yellow security jacket that drivers are legally required to possess in their cars, was suggested as a symbol to express support for the protests. Much like for other contemporary grassroots movements, social media (particularly Facebook) played an important role in generating collective selfhood and mobilizing collective action (Adam-Troian, Mahfud, Urbanska, \& Guimond, 2021). The relationship between online and offline mobilization was reciprocal as street protests increased online support for the movement (Boyer, Delemotte, Gauthier, Rollet, \& Schmutz, 2020). The high level of reliance on social media should not, however, be taken to imply that the YV were mainly an online phenomenon. Offline discussions held among supporters during local road blockages 
as well as during national assembly meetings also played an important role in binding the movement together and in politicizing the large number of first-time protestors (Reungoat, Jouhanneau, \& Buton, 2020).

The YV differed from previous French protest movements due to its bottom-up organisation and its active rejection of leadership (Boyer et al., 2020). Social media played an important role in this regard, allowing YV supporters to coordinate their aims and actions horizontally through different online channels (Shultziner \& Kornblit, 2020). Supporters could plan and announce local protests as independent online events and list them on websites that depicted YV activities nationwide. Beyond these online information hubs, the movement rejected any form of central organization, leadership, or spokespersons and expelled those who claimed to represent the movement. This rejection extended to any type of political body such as parties or trade unions, towards which YV supporters in general appeared highly sceptical (Guerra, Alexandre, \& Gonthier, 2019). As noted by Shultziner and Kornblit (2020), the horizontal character of the YV was comparable to other grassroots movements like the Occupy Wall Street Movement that started in the Unites States or the early Spanish Indignados Movement. However, in contrast to such "public square" movements, YV's actions were concentrated largely on rural and suburban areas where protestors hit critical economic arteries, mainly by blocking roundabouts (Reungoat et al., 2020).

A remarkable aspect of the YV movement is the broad amount of support it received from French society. Polls indicated that roughly $70 \%$ of French citizens sympathized with the movement right from its early days (Statista, 2018). Jetten, Mols, and Selvanathan (2020) attributed the success of the movement to widely held perceptions of an unjustified wealth gap between members of "ordinary society" and "the elite." The authors reviewed evidence indicating that tax policies introduced by the Macron administration which has been leading France since 14 May 2017 placed a disproportionate load on citizens with lower income levels. Indeed, public approval of the presidential cabinet was extremely low at the time the YV movement was growing, as many citizens disagreed with the liberal market agenda of President Emmanuel Macron. Most likely, the iconic claim according to which elites worry about the end of the world while YV supporters worry about the end of the month (e.g. Bock, 2018) resonated with perceptions held by the French working and lower middle classes who were facing increasingly precarious living conditions and were unwilling to bear the brunt of challenging socio-political transitions (Martin \& Islar, 2021). Grossman (2019) further understands the YV as a symptom of a dysfunctional electoral system that favours candidates who are willing to make bold but unrealistic promises to gather voter support. According to Grossman's analysis, Macron has been no exception in this regard by introducing himself as anti-establishment candidate who then widely failed to change the political class. The excessive police force that was used to contain the protests might explain the high level of support for the movement even after parts of the protests escalated into violence (Jetten et al., 2020).

A remaining question, however, is how a movement of such diverse social composition and without any central organization could act so efficiently and over a considerable period of time (i.e. until the onset of the COVID-19 pandemic). The next section offers an explanation to this puzzle, arguing that populism may serve as a shared belief set that can unite people with otherwise different and even competing ideological outlooks.

\section{Populism as Shared Belief Set}

The present research addresses the previously articulated but barely tested hypothesis that populism can serve as a common ideological base for people with different socio-demographic and ideological backgrounds (e.g., Bristow, 2019; Lobera, 2019). Acting against an undesired elite which is perceived as a common enemy could thereby at least temporally overcome partisan divisions for the sake of a greater goal. Similar phenomena have already been observed in other grassroots contexts, including the Turkish Gezi Park and Chilean Spring protests (Acar \& Uluğ, 2016; Somma, Bargsted, Disi Pavlic, \& Medel, 2021).

To approach populism as a shared belief set, we borrow from Mudde's (2004) influential definition of populism as a "thin-centred ideology". According to this definition, populism only contains a narrow socio-political agenda that is based on a normative distinction between a glorified community of "ordinary men and women" (i.e. the people) who stand in opposition to an overprivileged political "elite". Its thin-centred character enables populism to embrace anti-systemic ideas from different political sides. However, while vertical distinctions between "the people" and "the elite" are central to left and right-wing populism, the latter additionally involves horizontal distinctions between 
the "native majority" and immigrants (Obradović, Power, \& Sheehy-Skeffington, 2020). Left-wing populism (e.g., as embraced by the younger anti-austerity parties in southern Europe) therefore behaves more inclusively towards larger parts of society, while populist parties, with vaguer ideological positions such as the Italian Five Star Movement, fall somewhere in between inclusion and exclusion (Font, Graziano, \& Tsakatika, 2021). A similar pattern can be observed in France, where vertical features of populism are endorsed by the left-wing populist party La France Insoumise led by Jean-Luc Mélenchon, as well as by the right-wing populist party Le Rassemblement National led by Marine Le Pen. However, in line with the distinctions set out above, only the right-wing populist Rassemblement National harnesses cultural grievances resulting from horizontal distinctions, thus making it particularly appealing for those who consider themselves as the losers of globalisation (Ivaldi, 2019).

Scholars have argued that because of its diversity, the YV cannot be clearly located on a left-right continuum. This observation might also explain why established populist actors from both sides failed to monopolize the movement (Adam-Troian et al., 2021). Guerra et al. (2019) demonstrated that even if YV supporters had tended to support candidates from the political extremes in the past, most of them considered their political views as inconsistent with ideological distinctions on a left vs. right continuum. However, the same data revealed that YV supporters were holding pronounced populist attitudes that depict "the people" and "the elite" as antagonistic agents. Drawing on this observation the present research adopts a "minimal operationalization" of populism that permits researchers to explore populist sentiments among citizens empirically (Spruyt, Keppens, \& Van Droogenbroeck, 2016). This operationalization of populism includes, 1) a representation of society that distinguishes between two homogenous groups, "the people" and "the elite", 2) an assumption of an antagonistic relationship between "the people" and "the elite", 3) a moral definition of "the people" as the virtuous majority and of "the elite" as a malicious powerful minority, and 4) the assumption that the general will of "the people" reflects the ultimate source of legitimacy in political decisions. We consider this approach to be particularly well-suited for the scope of the present research for two reasons. First, it allows us to understand populism as a shared belief set that overlies other ideological outlooks. Second, it permits us to focus on the "demand side" of populism and its relationship to anti-government protest.

Indeed, relatively little is known to date about how populist demands shape political behaviour. A recent contribution based on survey data from the Netherlands found that populism related positively to direct and deliberative forms of political participation and support for democracy (Zaslove, Geurkink, Jacobs, \& Akkerman, 2021). These findings overlap with reports from Guerra et al. (2019) according to which YV supporters held increased levels of political interest and support for direct democracy. However, contrary to our theoretical expectations, Zaslove et al. (2021) reported a negative relationship between populist attitudes and protest behavior. The authors explained this result in terms of conflicts between populist preferences for direct and unmediated participation, on the one hand, and the fundamentally pluralistic nature of protests, on the other. The idea that populism and pluralism are inevitably antagonistic, however, has been subject to empirical and theoretical challenges (Hawkins, Riding, \& Mudde, 2012; Warren, 2020). Indeed, not only was the YV movement able to mobilize populist sentiments beyond ideological boundaries but also to develop efficient strategies to prevent pluralism from hampering the movement's internal discourse. Interviews conducted by Reungoat et al. (2020) indicated that the rejection of ideology-based partisan division within the YV movement was by no means coincidental, but instead a strategic norm to avoid conflict among supporters. Not only did the movement prevent individuals from displaying potential political affiliations but supporters also consciously disregarded discussions on highly divisive topics like migration. Consequently, despite agreeing with Zaslove et al. (2021) that the effects of populism on political action may be altered by contextual factors we predict a positive relationship between populist attitudes and protesting in the present context of YV supporters.

To sum up, the present research empirically examines whether a shared populist worldview can mobilize cross-ideological, leaderless, large-scale protests as exemplified by the YV movement. In the next section, we will focus on the role of relative deprivation as a motivational underpinning that provides fertile ground for the initial emergence of populist sentiments. 


\section{Relative Deprivation and Populist Attitudes}

Relative deprivation has been associated with contemporary uprisings around the globe. According to relative deprivation theory (Crosby, 1976), people do not make judgements of fairness in absolute terms in the social context but by their perception of how they are treated and what they are entitled to in comparison to other people or groups. Consequently, people can experience relative deprivation in various contexts that cause people to feel unfairly disadvantaged (Power, Madsen, \& Morton, 2020). For example, Power (2018) documented how relative deprivation that rose from an experienced inequality in the recovery of different households in Ireland after the economic crisis fuelled large-scale protests after an announced water tax. Comparably, researchers explained the Chilean Spring that started from an announced increase in public transport charges, with grievances resulting from severe inequalities between members of the elites and the social majority (Somma et al., 2021). In a similar vein, relative deprivation has been theoretically associated with the rise of the YV movement (Jetten et al., 2020; Royall, 2020). Nevertheless, to the best of our knowledge, no empirical data has validated this assumption. To address this shortcoming, we will now develop a definition of relative deprivation that allows us to study relative deprivation as motivational driver for protest through the embracing of populist attitudes.

Depending on the framework used for comparison, relative deprivation can manifest itself as individual relative deprivation (IRD) or group relative deprivation (GRD) (Runciman, 1966). IRD and GRD thereby predict distinct attitudinal and behavioural responses (Anier, Guimond, \& Dambrun, 2016). Higher IRD is associated with poorer individual-level outcomes, such as lower academic achievement or psychological stress (Smith et al., 2012). GRD, on the other hand, represents a robust and relevant concept in the explanation of intergroup attitudes and collective action (Abrams \& Grant, 2012; Guimond \& Dambrun, 2002). Notably, previous findings suggested that relative deprivation reflects an important element underlying support for populist leaders and ideas (Noury \& Roland, 2020; Obradović et al., 2020). However, given the malleability of populism and the different contexts and comparisons underlying experiences of relative deprivation, some further clarification seems necessary. For instance, Spruyt et al. (2016) used a 4-item measure of relative deprivation that conflated items measuring IRD (e.g., "I never received what I in fact deserved") and GRD (e.g., "If we need anything from the government, ordinary people like us always have to wait longer than others"), thus making it impossible to know what facet of relative deprivation better predicts populist sentiments. Conversely, findings presented by Marchlewska, Cichocka, Panayiotou, Castellanos, and Batayneh (2018) indicated that GRD, but not IRD, predicted support for Brexit and former presidential candidate Trump due to enhanced collective narcissism.

It has been claimed that YV supporters constructed collective selfhood around shared grievances caused by socio-economic inequalities (Jetten et al., 2020; Royall, 2020). As pointed out by Jetten et al. (2020), France was not facing any severe widening of the wealth gap at the time the YV movement gained momentum. Nevertheless citizens with lower income levels disproportionally were affected by increased tax loads, growing precarity, and low levels of social mobility. Following Klandermans (2014), we assume that a common sense of relative deprivation lay at the origin of the YV movement, mobilizing people to come together to wage a power struggle against a common enemy. Consequently, we expect GRD to be a better predictor of protest participation than IRD. A final question to be addressed is that of which unfavourable intergroup comparisons fuelled the formation of populist beliefs among YV supporters.

As outlined above, populism entails a vertical social distinction between "the people" and "the elite." GRD research, however, has a long tradition identifying horizontal comparisons between the "native majority" and immigrants (Pettigrew, 2016). Nevertheless, it is critical to note that this body of research, rather than dealing with the concept of GRD as such, should be seen as referring to a particular type of GRD that can be more properly qualified as horizontal GRD (hGRD) - a critical component of right-wing populism (Urbanska \& Guimond, 2018; van den Bos, 2020). In contrast, the type of GRD most relevant to populism should entail a vertical comparison between "the people" and "the elite". To validate this assumption, the present research additionally includes an indicator of vertical group relative deprivation (vGRD). Based on the definition of populism used here, as well as on the fact that the YV cannot be allocated to either side of the political spectrum, we expect vGRD to be the most relevant indicator of relative deprivation for the context of the present research. Moreover, and in line with previous research, we expect GRD to promote collective action not simply because people engage in a particular intergroup comparison (cognitive component), but because this comparison generates strong intergroup emotions of anger, resentment, or moral outrage. Thus, taking into account the 
important function of affect in underpinning protest (Morales, Ionescu, Guegan, \& Tavani, 2020; van Zomeren, Spears, Fischer, \& Leach, 2004) and populist support (Lüders, Mühlberger, \& Jonas, 2020), we conceptualize vGRD as "angry frustration" (Power, 2018) stemming from intergroup comparisons between the "people" and the "elite".

\section{Present Research}

Which dimensions of relative deprivation motivate people to engage in anti-government protest? Can support for populism as a shared belief set help explain the relations between relative deprivation and collective action? We examine these questions within the context of the YV movement in order to understand the emergence of large-scale and leaderless anti-government protesting. Our study uses a sample of French citizens recruited while the YV protests were at their peak. The dependent variable measures participants' amount of participation in YV protests over a course of 30 days.

The following hypotheses will be tested ${ }^{1}$ :

The first step in our analysis concerns the relationship between different dimensions of relative deprivation and YV protest participation.

H1: YV protest participation will be best predicted by perceptions of vertical group relative deprivation revealing unfavourable comparisons between "ordinary citizens" and the "ruling elite".

The second part of the analysis tests how indicators of relative deprivation correspond to populist attitudes.

H2: Populist attitudes will be best predicted by vertical group relative deprivation.

The third part of the analysis tests the proposed mediation model, including our key hypothesis that populist attitudes account for the proposed relationship between relative deprivation and protest participation.

H3: Populist attitudes will mediate the formulated relationships between relative deprivation and $Y V$ protest participation.

A final hypothesis tests the context-specific prediction that ideological outlooks operationalized on a left-right continuum cannot account for any of the assessed YV-related phenomena.

H4: Ideological self-placement will neither significantly predict populist attitudes nor YV protest participation.

\section{Method and Materials}

\section{Sample}

Our pre-registration plan included a minimum sample size of $N=400$ with no upper limit. We ultimately recruited a sample of $N=562$ French residents between 21 December 2018 and 6 January 2019 through a Facebook page dedicated to the study as well as through personal networks. We justify this choice through the movement's strong social media presence. Participants had to fill in an online survey, which took around 10 minutes to complete. While participation was voluntary, the participants were included in a draw for a 50-euro voucher. A sensitivity power analysis for linear multiple regressions with up to four predictors (Faul et al., 2009) indicated that we could reliably detect small effects with a minimum effect size of $f^{2}=.02$ given $\beta=.90, \alpha=.05$.

\footnotetext{
1) An initial pre-registration of the research project by the second author, did not distinguish between a horizontal and a vertical dimension of GRD. The distinction was suggested by the first author before re-analysing the data. The original pre-registration statement can be accessed here: http://aspredicted.org/blind.php?x=rv38n6
} 
The sample included $58 \%$ female and $42 \%$ male participants aged between $24-74$ years $\left(M_{\text {Age }}=47.6, S D=14\right)$. $44 \%$ of the sample had obtained a university degree. $31 \%$ completed some secondary education, $12 \%$ obtained primary education, and another $12 \%$ obtained vocational qualifications ( $1 \%$ did not disclose educational information). The Supplementary Files include additional information on the ideological and socio-political viewpoints of the sample. In a nutshell, most participants hold negative perceptions about France's current and future economic situation and desired a lower salary gap. Additionally, a considerable number of participants indicated past (49.3\%) or present (34.5\%) support for political candidates from the extreme left or the extreme right. However, $25.4 \%$ reported that they would not vote if there would be an election today. $49.3 \%$ reported that they stayed away from the final ballot of the last presidential election in which Emanuele Macron won against far-right candidate Marine Le Pen.

\section{Measures}

As the data for this study was collected as a part of a larger study on the Yellow Vests movement in France, we only use a subset of the measures in the present analysis. Other parts of the survey were presented in other manuscripts (Adam-Troian et al., 2021; Urbanska, Pehrson, \& Guimond, 2021). All variables collected as a part of the study are disclosed in the Supplementary Materials. The current analysis involves the following variables.

\section{Political Ideology}

Political ideology was measured with a single 10-point item asking participants "Where would you classify yourself on a scale where 1 indicates the most left-wing position and 10 indicates the most right-wing position?”

\section{Relative Deprivation}

We included three distinct indicators of relative deprivation. Single-item measures of individual relative deprivation and horizontal group relative deprivation were taken from previous research (e.g., Urbanska \& Guimond, 2018) and followed a 5 -point scale, ranging from $1=$ much better to $5=$ much worse.

Participants indicated individual relative deprivation (IRD) by responding to the question "If you were to compare your personal economic situation to that of most French people, would you say your economic situation is...?"

A second item assessed horizontal group relative deprivation (hGRD) asking participants "If you were to compare the economic situation of French people to that of immigrants living in France, would you say that the economic situation of French people is...?"

A third item measuring vertical group relative deprivation (vGRD) was created for the purpose of this research and asked participants "If you were to compare the economic situation of most French people with that of the ruling elite in power in France, how would you feel...?" The item followed a 3-point format ranging from $1=$ very angry to $3=$ not angry. We recoded the item so that higher values indicated higher levels of vGRD.

\section{Populist Attitudes}

Populist attitudes were measured with 8 items (Spruyt et al., 2016). The items were rated on a 5-point scale format ranging from 1 = strongly disagree to $5=$ strongly agree. Examples of these items include: "Politicians should follow only the will of the people." A confirmatory factor analysis based on a maximum likelihood estimation confirmed the single structure of the scale $(\mathrm{CFI}=.96, \mathrm{RMSEA}=.09$, SRMR $=.04)$. All factor loadings were significant and above conventional thresholds $(.51-.86$.). Scale reliability was satisfactory $(\alpha=.89)$.

\section{Yellow Vests Protest Participation}

One question assessed participants' protest engagement: “Over a total of 30 days, how many days would you say you have participated in $[Y V]$ actions since the movement began last November? Thank you for responding with a number between 0 and $30 . " 47 \%$ of the sample $(n=207)$ reportedly participated in one or more protests (see Supplementary Materials for additional information). 


\section{Results}

\section{Predicting Protest Participation and Populist Attitudes Through Relative Deprivation}

We tested two different multiple linear regression (MLR) models to examine the effect of different indicators of relative deprivation on protest participation (H1) and populist attitudes (H2). Each MLR model was followed by a relative weight analysis (relaimpo package for R; Grömping, 2006) to test for significant differences between the predictors. Missing values were excluded from the analysis. Table 1 provides an overview of the reported variables.

Table 1

Descriptives and Zero Order Correlations of the Reported Variables

\begin{tabular}{|c|c|c|c|c|c|c|c|c|c|}
\hline Variable & $M$ & $S D$ & Skewness & Kurtosis & 1 & 2 & 3 & 4 & 5 \\
\hline 1. Pol. Ideology & 4.44 & 2.10 & .53 & 2.88 & & & & & \\
\hline 2. IRD & 2.91 & .87 & .31 & 3.35 & .04 & & & & \\
\hline 3. hGRD & 2.49 & 1.05 & .41 & 2.63 & $.38^{* * *}$ & $.24^{* * *}$ & & & \\
\hline 4. vGRD & 2.73 & .58 & 2.02 & 5.85 & $-.09^{*}$ & $.10^{* *}$ & $.26^{* * *}$ & & \\
\hline 5. Populist Attitudes & 4.03 & .83 & 1.18 & 3.95 & -.02 & $.20^{* * *}$ & $.37^{* * *}$ & $.73^{* * *}$ & \\
\hline 6. YV Protest Participation & 3.74 & 7.19 & 2.28 & 7.61 & .01 & $.17^{* * *}$ & $.25^{* * *}$ & $.18^{* * *}$ & $.26^{* * *}$ \\
\hline
\end{tabular}

${ }^{*} p<.05 .{ }^{* *} p<.01 .{ }^{* * *} p<.001$.

The first model tested H1 and regressed indicators of political ideology, IRD, hGRD, vGRD against protest participation (Table 2). Together, the significant predictors explained $8.9 \%$ of the variance in protest participation, $F(4,534)=14.18, p$ $<.001$. As expected, political ideology (self-placement on a left-right continuum) did not significantly predict YV protest participation, consistent with H4. Conversely, all three indicators of relative deprivation significantly and positively related to protest participation. Contrary to our prediction, relative weight analysis indicated no differences between the significant predictors. Consequently, we reject $\mathrm{H} 1$.

\section{Table 2}

MLR Model Predicting YV Protest Participation

\begin{tabular}{|c|c|c|c|c|}
\hline Predictor Variable & $b(S E)$ & $\boldsymbol{\beta}$ & $t$ & $p$ \\
\hline Political Ideology & $-.24(.16)$ & -.07 & -1.50 & .14 \\
\hline IRD & $.91(.35)$ & .11 & 2.58 & .01 \\
\hline hGRD & $1.59(.33)$ & .23 & 4.78 & $<.001$ \\
\hline vGRD & $1.31(.54)$ & .11 & 2.43 & .02 \\
\hline Relative Differences & Difference Score & & \multicolumn{2}{|c|}{$5000 \times$ Bootstrapped 95\% CI } \\
\hline Pol. Ideology - IRD & .02 & & \multicolumn{2}{|c|}{$-.01 ; .01$} \\
\hline Pol. Ideology - hGRD & .05 & & \multicolumn{2}{|c|}{$.02 ; .08$} \\
\hline Pol. Ideology - vGRD & .02 & & \multicolumn{2}{|c|}{$.01 ; .03$} \\
\hline IRD - hGRD & -.03 & & \multicolumn{2}{|c|}{$-.08 ; .01$} \\
\hline IRD - vGRD & .01 & & \multicolumn{2}{|c|}{$-.03 ; .03$} \\
\hline hGRD - vGRD & .03 & & \multicolumn{2}{|c|}{$-.01 ; .07$} \\
\hline
\end{tabular}

Note. $\mathrm{vGRD}$ = Vertical Group Relative Deprivation; hGRD = Horizontal Group Relative Deprivation; IRD = Individual Relative Deprivation. Missing Values $=23$.

A second model tested $\mathrm{H} 2$, which held that populist attitudes are best predicted by vGRD. We regressed indicators of political ideology, vGRD, hGRD, IRD against populist attitudes (Table 3). The significant predictors explained $58 \%$ of the variance in populist attitudes, $F(4,531)=185.5, p<.001$. Populist attitudes related significantly and positively to all three 
indicators of relative deprivation. Relative weight analysis indicated that vGRD was the most important predictor of populist attitudes. Additionally, hGRD was relatively more important in predicting populist attitudes than IRD. In sum, the results support H2. Additionally, the findings corroborate H4, which predicted a null effect of political ideology on protest participation and populist attitudes in the context of the YV movement.

Table 3

MLR Model Predicting Populist Attitudes

\begin{tabular}{|c|c|c|c|c|}
\hline Predictor Variable & $b(S E)$ & $\beta$ & $t$ & $p$ \\
\hline Political Ideology & $-.01(.01)$ & -.03 & -1.06 & .290 \\
\hline IRD & $.09(.03)$ & .09 & 3.10 & .002 \\
\hline hGRD & $.15(.03)$ & .18 & 5.59 & $<.001$ \\
\hline vGRD & $.97(.04)$ & .68 & 22.80 & $<.001$ \\
\hline Relative Differences & Difference Score & & \multicolumn{2}{|c|}{$5000 \times$ Bootstrapped 95\% CI } \\
\hline Pol. Ideology - IRD & .02 & & \multicolumn{2}{|c|}{$-.01 ; .04$} \\
\hline Pol. Ideology - hGRD & .08 & & \multicolumn{2}{|c|}{$.05 ; .11$} \\
\hline Pol. Ideology - vGRD & .47 & & \multicolumn{2}{|c|}{$.41 ; .53$} \\
\hline IRD - hGRD & .06 & & \multicolumn{2}{|c|}{$.02 ; .10$} \\
\hline IRD - vGRD & .46 & & \multicolumn{2}{|c|}{$.39 ; .52$} \\
\hline hGRD - vGRD & .40 & & \multicolumn{2}{|c|}{$.32 ; .47$} \\
\hline
\end{tabular}

Note. vGRD = Vertical Group Relative Deprivation; hGRD = Horizontal Group Relative Deprivation; IRD = Individual Relative Deprivation. Missing Values $=26$.

\section{Populist Attitudes Mediate Protest Participation}

We used structural equation modelling (SEM) to test our key hypothesis, according to which populist attitudes mediate the effect of GRD on YV protesting (H3). We analyzed the data with the lavaan package for R (Rosseel, 2012). Parameters were estimated based on maximum likelihood and missing data was excluded from analysis (i.e. listwise deletion). Bootstrapped estimates were employed with 5000 samples and 95\% confidence intervals. We allowed measurement errors to covary between indicators of relative deprivation (i.e. hGRD, vGRD, IRD). Political orientation was added as covariate. Figure 1 provides a conceptual representation of the model.

Figure 1

Conceptual Representation of the Proposed Mediation Model

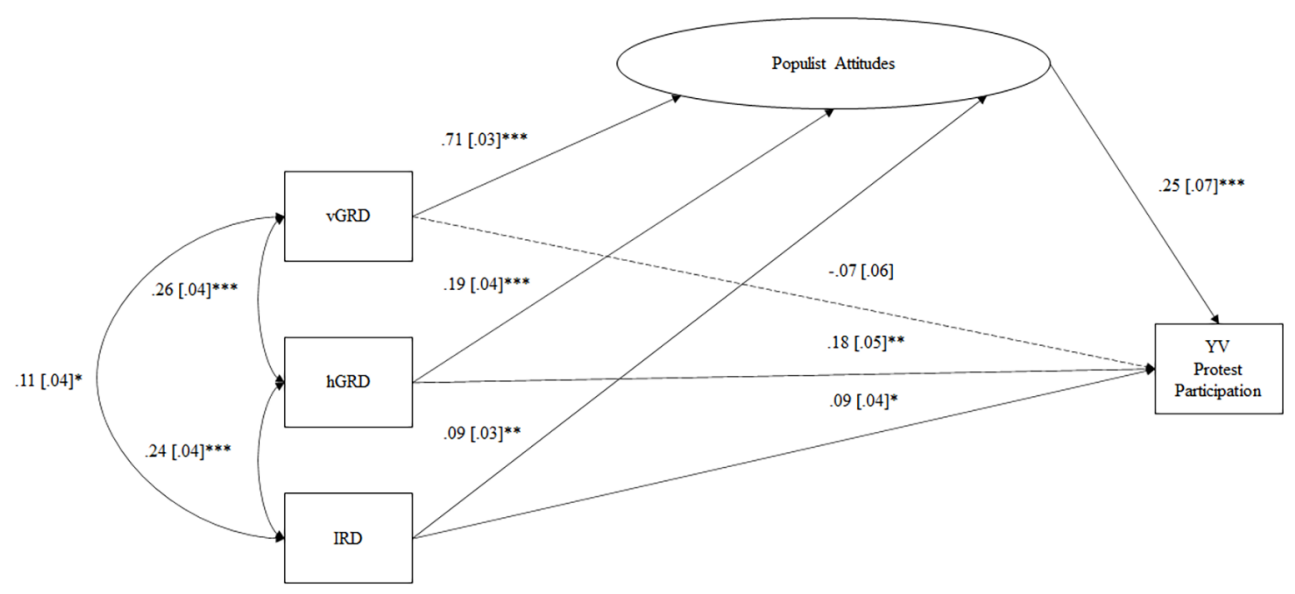

Note. Values show standardized regression coefficients and standard errors (in brackets).

${ }^{*} p<.05 .{ }^{* *} p<.01 .{ }^{* * *} p<.001$. Covariate: Political Ideology. Missing Values $=26$. 
We regressed all three indicators of relative deprivation onto protest participation and entered populist attitudes as a mediator. With the exception of the sample-size sensitive $\chi^{2}$ test, fit indices indicated an acceptable model fit, $\chi^{2}(58)=$ $298.65, p<.001, \mathrm{CFI}=.92$, RMSEA $=.09$, SRMR $=.06$. All indicators of group deprivation positively related to populist attitudes, vGRD: $B=.71, S E=.03, p<.001,95 \%$ CI [.66, .77]; hGRD: $B=.19, S E=.04, p<.001,95 \%$ CI [.12, .27]; IRD: $B$ $=.09, S E=.03, p=.003,95 \% \mathrm{CI}[.03, .14]$. Populist attitudes positively related to protest participation, $B=.25, S E=.07$, $p<.001,95 \%$ CI $[.12, .38]$. An analysis of indirect effects indicated that populist attitudes mediated the effects of relative deprivation on $\mathrm{YV}$ protesting, thereby corroborating $\mathrm{H} 3$. This was the case for both indicators of group relative deprivation, vGRD, $B=.18, S E=.05,95 \% \mathrm{CI}[.09, .28]$, and hGRD, $B=.05, S E=.02,95 \% \mathrm{CI}[.02, .08]$. Unexpectedly, the indirect effect of IRD on protest participation through populist attitudes was also significant, $B=.02, S E=.01,95 \% \mathrm{CI}$ $[.01, .04]$. Notably, after accounting for populist attitudes as mediator, the effect of vGRD on protest participation was no longer significant, $B=-.07, S E=.06,95 \% \mathrm{CI}[-.20, .05]$. Conversely, hGRD still directly related to protest participation, $B=.18, S E=.05,95 \%$ CI $[.09, .28]$, as did IRD, $B=.09, S E .04,95 \%$ CI $[.01, .17]$.

In sum, populist attitudes fully explained the effect of vGRD on YV protesting and partially mediated the effect of hGRD and IRD on anti-government protesting (Table 4).

\section{Table 4}

Indirect, Direct, and Total Effects of Relative Deprivation Indicators on YV Protest Participation Through Populist Attitudes

\begin{tabular}{lccc}
\hline Effect & IRD & hGRD & vGRD \\
\hline Indirect Effect & $B=.02, S E=.01$, & $B=.05, S E=.02$, & $B=.18, S E=.05$, \\
& $95 \% \mathrm{CI}[.01, .04]$ & $95 \% \mathrm{CI}[.02, .08]$ & $95 \% \mathrm{CI}[.09, .27]$ \\
Direct Effect & $B=.09, S E=.04$, & $B=.18, S E=.05$, & $B=-.07, S E=.06$, \\
& $95 \% \mathrm{CI}[.01, .17]$ & $95 \% \mathrm{CI}[.09, .28]$ & $95 \% \mathrm{CI}[-.20, .05]$ \\
Total Effect & $B=.11, S E=.04$, & $B=.23, S E=.05$, & $B=.11, S E=.03$, \\
& $95 \% \mathrm{CI}[.03, .19]$ & $95 \% \mathrm{CI}[.14, .33]$ & $95 \% \mathrm{CI}[.04, .17]$ \\
\hline
\end{tabular}

Note. Regression values indicated by standardized BETA coefficients.

\section{Discussion}

The present research approached populism as a bottom-up phenomenon to understand how shared grievances among YV supporters could translate into large scale anti-government protests. In doing so, the presented results contribute to the understanding of the demand side of populism, indicating that populist worldviews may serve as a "thin centred" belief set that holds the potential to mobilize protest across ideological boundaries and in the absence of leaders or central organizations.

\section{Relative Deprivation and YV Protest Participation}

In a first step, we compared relationships between different dimensions of relative deprivation (i.e. hGRD, vGRD, IRD) and YV protest participation. All predictors related significantly and positively to protesting. Testing for the relative importance of the different predictors led us to reject our first hypothesis, according to which vGRD would be the main driver for YV protesting. Consequently, the obtained findings demand further reflection on the role of hGRD and IRD as motivational forces underlying protest. Considering that the YV movement attracted people with different ideological viewpoints, it seems plausible that also xenophobic grievances were involved in the mobilization process. Indeed, although not representative, xenophobic incidents reportedly occurred as by-products of YV activities (e.g. L'Obs, 2018). While such events, stay in stark contrast to the movement's expressed demands to move society towards social and economic justice, citizen participation, and sustainability (Wilkin, 2020), they reveal insights into competing motivations that might be better tackled with more fine-tuned measures. An explanation for the unexpected strong relationship 
between IRD and protesting could derive from the cross-sectional design which prevented us from gaining insights in the movement's identity dynamics. Our model proposes a causal effect from GRD to collective action. Although previous findings support this direction, the natural relationship between GRD and collective action should rather be seen as reciprocal (for a more exhaustive analysis see Klandermans, 2014). It is possible that the act of protesting itself could lead to a re-categorization of the relatively deprived personal self into a collective one (Drury \& Reicher, 2000). Following this reasoning, one might assume an opposed development of IRD and GRD impacts on protesting over time. One critical point must be mentioned, namely that the result that all three indicators of relative deprivation together accounted for less than $9 \%$ of variance in protesting. Thus, although the obtained findings provide an important reminder to distinguish between different forms of relative deprivation, they also call for simultaneous comparisons with other drivers of protest as outlined in the collective action literature (e.g. van Zomeren et al., 2004).

\section{Relative Deprivation and Populism}

Our second hypothesis claimed that populist attitudes largely emerge from feelings of relative deprivation in which an "ordinary majority" contrasts its situation unfavourably with that of a "ruling elite." Our findings support this assumption, indicating that vGRD better predicted populist attitudes than any other considered dimension of relative deprivation. Our data therefore corroborates claims according to which vertical social distinctions lie at the core of populist worldviews. We acknowledge that vGRD and populism may not always be distinguishable at the experiential level (as indicated by their strong intercorrelation). Nevertheless, we see some merit in distinguishing between vGRD as a motivational impulse and populism as an ideological guide for action when predicting political behaviour. For instance, while relative deprivation is widely acknowledged as a driver for protest, the relationship between populism and protest might be sensitive to contextual influences and manifest in different directions (e.g. Zaslove et al., 2021).

It is worth noting that, although our measure of populist attitudes did not explicitly address anti-immigrant sentiments, populist attitudes were nevertheless related to perceptions that immigrants are better off than French citizens (i.e. hGRD). Zero-order correlations showed that populist attitudes were not significantly associated with ideological self-placements located on a left-right continuum and our sample was even slightly left-leaning. We assume that the measure of populism we used implicitly captured nativistic interpretations of society rooted in unfavourable comparisons with immigrants. This explanation resonates with the proposed ideological flexibility of populism as a "thin ideology" that can harness grievances from different sides of the ideological spectrum. While in practice, this flexibility may help explain the potential appeal of populism to larger parts of society, it reminds researchers who seek to measure "pure populism" to control more carefully for confounds with other ideological features.

\section{Populism as Mediator}

Testing our third hypothesis, we observed that populist attitudes fully accounted for the relationship between vGRD and protesting (but only partially for the corresponding relationships between hGRD and IRD and protesting). Given that we initially expected vGRD to be the main driver for YV protesting through populist attitudes, this finding comes close to our predicted model. The observed relationship between populism and protest participation of $r=.26$, however, may be smaller than previous research on the YV movement would suggest. At this point, we can only speculate about what other factors may have helped mobilize the protests. It is possible that populist sentiments were mainly embraced by the politicized part of the movement, whereas other parts used protesting as a channel to express more deeply rooted psychological concerns (Mahfud \& Adam-Troian, 2021). Yet others may seek comfort from psychological benefits that emerge from the acquisition of a new social identity (Jetten, Haslam, \& Alexander, 2012; for empirical evidence, see Adam-Troian et al., 2021).

The comparatively weak effect of populism on protesting could also help understand why the YV maintained their horizontal character whereas other grassroots movements adopted a centralistic organisation. Interviews conducted by de Nadal (2021), provide insights into the internal decision-making processes that gradually transformed the initially horizontalist Indignados movement into the verticalist political party Podemos. Unlike the YV movement, Podemos sought to transform grievances into political power by acting as a political party. Inspired by other left-wing populist movements in Latin America, Podemos chose to centre around its charismatic leader Pablo Iglesias (de Nadal, 2021). 
The YV movement clearly chose an opposite strategy by rejecting any attempts from individual supporters to enter the institutional political arena. Consequently, none of the lists of YV activists that were formed prior to the subsequent European elections eventually achieved the $5 \%$ threshold needed to get candidates into the EU parliament.

In sum, the present research allows us to draw the following conclusion. First, perceptions of relative deprivation at different levels may fuel the formation of large-scale protest in the absence of political leaders. Second, this relationship may be partially explained through emerging populist worldviews that split society into two antagonistic groups: the "people" and "the elite." Third, when comparing different dimensions of relative deprivation, populist attitudes can be best predicted on the basis of unfavourable comparisons between an ingroup of "ordinary men and women" and an outgroup of "elite members". Finally, and in support of our last hypothesis (H4), left-right ideological self-placement predicted neither populist attitudes nor YV protesting, thus corroborating our and previous conclusions (e.g. Guerra et al., 2019) according to which the YV movement does not locate itself within established ideological categories.

\section{Limitations and Future Research}

We would like readers to consider the following limitations. First, many of the employed measures relied on single items, which are not optimal for covering the entire composition of a construct. However, given that most of our single-item measures have been widely used in the past (e.g. Pettigrew et al., 2008) or related to actual behaviour, we believe that this limitation does not seriously impair the overall validity of our measures.

Second, in proposing a distinction between different levels of GRD, we endowed our novel measure of vGRD with an affective focus (i.e. felt anger), thus distinguishing it from traditional measures which rely on cognitive appraisals (i.e. being better/worse off than). This conceptual confusion prevents any definite conclusions about the relative importance of various types of relative deprivation. Indeed, one solution to overcome this problem could be to simultaneously measure affective and cognitive indicators of relative deprivation to control for their respective effects.

Third, none of the employed measures permits us to differentiate between proximal and distal goals that motivated people to engage in YV protests. In other words, based on the present findings, we cannot tell whether populist worldviews and their concrete manifestation in anti-government protesting should be understood as a short-term syndrome enabling protesters to express frustration or as a means to achieve distal goals aimed at sustainably reducing perceived inequalities.

Finally, as our research reveals insights into the potential relationships between the motivations, cognitions, and actions underlying protest, future studies will need to take a deeper look at the social dynamics that underlie the formation of grassroots phenomena. The handling of attitude pluralism and the interactive development of collective selfhood in online and offline environments appears hereby particularly relevant (Quayle, 2020). Previous research also suggests that drivers of protest could be modulated based on previous activism experiences (Scafuto \& La Barbera, 2016). Consequently, future studies might test whether the proposed mechanism differ between activists and non-activists or change within protestors over time. In a wider context, researchers may seek to reveal interplays between people's collective memories of the past and imaginations of the future to understand the emergence of relative deprivation and protest under increasing global prosperity (Power, 2020).

Funding: This research was supported by the French National Research Agency (ANR-18-ORAR-0003; Adrian Lüders \& Robin Wollast), the European Research Council (No. 802421, Adrian Lüders), and the FLAG-ERA joint transnational call project, FuturICT 2.0 (Karolina Urbanska).

Acknowledgments: The authors have no support to report.

Competing Interests: The authors have declared that no competing interests exist.

Data Availability: For this article, a dataset is freely available (Lüders et al., 2021). 


\section{Supplementary Materials}

The Supplementary Materials contain data, codes, and material for this study (for access see Index of Supplementary Materials below).

\section{Index of Supplementary Materials}

Lüders, A., Urbanska, K., Wollast, R., Nugier, A., \& Guimond, S. (2021). Supplementary materials to "Bottom-up populism: How relative deprivation and populist attitudes mobilize leaderless anti-government protest" [Research data, code, and materials]. OSF. https://osf.io/bqmu3/

\section{References}

Abrams, D., \& Grant, P. R. (2012). Testing the social identity relative deprivation (SIRD) model of social change: The political rise of Scottish nationalism. British fournal of Social Psychology, 51, 674-689. https://doi.org/10.1111/j.2044-8309.2011.02032.x

Acar, Y. G., \& Uluğ, Ö. M. (2016). Examining prejudice reduction through solidarity and togetherness experiences among Gezi Park Activists in Turkey. Journal of Social and Political Psychology, 4, 166-179. https://doi.org/10.5964/jspp.v4i1.547

Adam-Troian, J., Mahfud, Y., Urbanska, K., \& Guimond, S. (2021). The role of social identity in the explanation of collective action: An intergroup perspective on the Yellow Vests movement. fournal of Applied Social Psychology, 51, 560-576.

https://doi.org/10.1111/jasp.12757

Anier, N., Guimond, S., \& Dambrun, M. (2016). Relative deprivation and gratification elicit prejudice: Research on the V-curve hypothesis. Current Opinion in Psychology, 11, 96-99. https://doi.org/10.1016/j.copsyc.2016.06.012

Bock, P. (2018, December 8). France's violent 'yellow vest' protests are about much more than a fuel tax. But is President Macron listening? NBC News. Retrieved from https://www.nbcnews.com/think/opinion/france-s-violent-yellow-vest-protests-are-about-much-more-ncna945481

Boyer, P. C., Delemotte, T., Gauthier, G., Rollet, V., \& Schmutz, B. (2020). The Gilets faunes: Offline and Online (CESifo Working Paper No. 8326). Center for Economic Studies and Ifo Institute (CESifo), Munich, Germany. Retrieved from https://www.cesifo.org/en/publikationen/2020/working-paper/gilets-jaunes-offline-and-online

Bristow, G. (2019). Yellow fever: Populist pangs in France: Reflections on the gilets jaunes movement and the nature of its populism. Soundings: A fournal of Politics and Culture, 72, 65-78. Retrieved from https://www.muse.jhu.edu/article/730849https://doi.org/10.3898/SOUN.72.04.2019

Crosby, F. (1976). A model of egoistical relative deprivation. Psychological Review, 83, 85-113. https://doi.org/10.1037/0033-295X.83.2.85

de Nadal, L. (2021). On populism and social movements: From the Indignados to Podemos. Social Movement Studies, $20(1), 36-56$. https://doi.org/10.1080/14742837.2020.1722626

Drury, J., \& Reicher, S. (2000). Collective action and psychological change: The emergence of new social identities. British fournal of Social Psychology, 39, 579-604. https://doi.org/10.1348/014466600164642

Faul, F., Erdfelder, E., Lang, A. G., \& Buchner, A. (2009). Statistical power analyses using G*Power 3.1: Tests for correlation and regression analyses. Behavior Research Methods, 41, 1149-1160. https://doi.org/10.3758/BRM.41.4.1149

Font, N., Graziano, P., \& Tsakatika, M. (2021). Varieties of inclusionary populism? SYRIZA, Podemos and the Five Star movement. Government and Opposition, 56, 163-183. https://doi.org/10.1017/gov.2019.17

Grömping, U. (2006). Relative importance for linear regression in R: The package relaimpo. fournal of Statistical Software, 17, 1-27. https://doi.org/10.18637/jss.v017.i01

Grossman, E. (2019). France's Yellow Vests - Symptom of a chronic disease. Political Insight, 10, 30-34. https://doi.org/10.1177/2041905819838152

Guerra, T., Alexandre, C., \& Gonthier, F. (2019). Populist attitudes among the French Yellow Vests. Populism, 3, 1-12. https://doi.org/10.1163/25888072-02021039

Guimond, S., \& Dambrun, M. (2002). When prosperity breeds intergroup hostility: The effects of relative deprivation and relative gratification on prejudice. Personality and Social Psychology Bulletin, 28, 900-912. https://doi.org/10.1177/014616720202800704 
Hawkins, K., Riding, S., \& Mudde, C. (2012). Measuring populist attitudes (Committee on Concepts and Methods Working Paper Series No. 55). Retrieved from https://www.concepts-methods.org/Files/WorkingPaper/PC_55_Hawkins_Riding_Mudde.pdf

Ivaldi, G. (2019). Populism in France. In D. Stockemer (Eds.), Populism around the world (pp. 27-47). Springer. https://doi.org/10.1007/978-3-319-96758-5_3

Jetten, J., Haslam, C., \& Alexander, S. H. (Eds.). (2012). The social cure: Identity, health and well-being. London, United Kingdom: Routledge.

Jetten, J., Mols, F., \& Selvanathan, H. P. (2020). How economic inequality fuels the rise and persistence of the Yellow Vest movement. International Review of Social Psychology, 33, Article 2. https://doi.org/10.5334/irsp.356

Klandermans, P. G. (2014). Identity politics and politicized identities: Identity processes and the dynamics of protest. Political Psychology, 35, 1-22. https://doi.org/10.1111/pops.12167

Lobera, J. (2019). Anti-austerity movements in Europe. In C. Flesher Fominaya \& R. Feenstra (Eds.), Routledge handbook of contemporary European social movements: Protest in turbulent times (pp. 267-283). London, United Kingdom: Routledge.

L’Obs. (2018, November 9). "Gilets jaunes": racisme, homophobie, violences et autres dérapages. L'OBS. Retrieved from https:/www.nouvelobs.com/societe/20181119.OBS5650/gilets-jaunes-racisme-homophobie-violences-et-autres-derapages.html

Lüders, A., Mühlberger, C., \& Jonas, E. (2020). Motivational and affective drivers of right-wing populism support: Insights from an Austrian Presidential Election. Social Psychological Bulletin, 15, Article e2875. https://doi.org/10.32872/spb.2875

Mahfud, Y., \& Adam-Troian, J. (2021). “Macron demission!”: Loss of significance generates violent extremism for the Yellow Vests through feelings of anomia. Group Processes \& Intergroup Relations, 24, 108-124. https://doi.org/10.1177/1368430219880954

Marchlewska, M., Cichocka, A., Panayiotou, O., Castellanos, K., \& Batayneh, J. (2018). Populism as identity politics: Perceived ingroup disadvantage, collective narcissism, and support for populism. Social Psychological \& Personality Science, 9, 151-162. https://doi.org/10.1177/1948550617732393

Martin, M., \& Islar, M. (2021). The 'end of the world' vs. the 'end of the month': Understanding social resistance to sustainability transition agendas, a lesson from the Yellow Vests in France. Sustainability Science, 16, 601-614. https://doi.org/10.1007/s11625-020-00877-9

Mazeau, G. (2019). Les « gilets jaunes » et la Révolution française: quand le peuple reprend l'histoire. In AOC « Gilets jaunes »Hypothèses sur un mouvement (pp. 107-112). Paris, France: La Découverte.

Morales, A., Ionescu, O., Guegan, J., \& Tavani, J. L. (2020). The importance of negative emotions toward the French government in the Yellow Vest movement. Revue Internationale de Psychologie Sociale, 33, Article 8. https://doi.org/10.5334/irsp.373

Mudde, C. (2004). The populist Zeitgeist. Government and Opposition, 39, 541-563. https://doi.org/10.1111/j.1477-7053.2004.00135.x

Noury, A., \& Roland, G. (2020). Identity politics and populism in Europe. Annual Review of Political Science, 23, 421-439. https://doi.org/10.1146/annurev-polisci-050718-033542

Obradović, S., Power, S. A., \& Sheehy-Skeffington, J. (2020). Understanding the psychological appeal of populism. Current Opinion in Psychology, 35, 125-131. https://doi.org/10.1016/j.copsyc.2020.06.009

Pettigrew, T. F. (2016). In pursuit of three theories: Authoritarianism, relative deprivation, and intergroup contact. Annual Review of Psychology, 67, 1-21. https://doi.org/10.1146/annurev-psych-122414-033327

Power, S. M. (2020). Why a richer world will have more civic discontent: The infinity theory of social movements. Review of General Psychology, 24, 118-133. https://doi.org/10.1177/108926802090732

Pettigrew, T. F., Christ, O., Wagner, U., Meertens, R. W., van Dick, R., \& Zick, A. (2008). Relative deprivation and intergroup prejudice. The fournal of Social Issues, 64, 385-401. https://doi.org/10.1111/j.1540-4560.2008.00567.x

Power, S. A. (2018). The deprivation-protest paradox: How the perception of unfair economic inequality leads to civic unrest. Current Anthropology, 59, 765-789. https://doi.org/10.1086/700679

Power, S. A., Madsen, T., \& Morton, T. A. (2020). Relative deprivation and revolt: Current and future directions. Current Opinion in Psychology, 35, 119-124. https://doi.org/10.1016/j.copsyc.2020.06.010

Quayle, M. (2020). A performative network theory of attitudes. PsyArXiv. https://doi.org/10.31234/osf.io/mh4z8

Reungoat, E., Jouhanneau, C., \& Buton, F. (2020, September). Becoming yellow vests: The politicization of ordinary citizens (France 2018-20) [Paper presentation]. APSA 2020 Virtual annual meeting: Democracy, difference, and destabilization, United States. https://doi.org/10.33774/apsa-2020-dz80s

Rosseel, Y. (2012). Lavaan: An R package for structural equation modeling. Fournal of Statistical Software, 48, 1-36. https://doi.org/10.18637/jss.v048.i02 
Royall, F. (2020). The Gilets Jaunes protests: Mobilisation without third-party support. Modern \& Contemporary France, 28 , 99-118. https://doi.org/10.1080/09639489.2019.1676217

Runciman, W. G. (1966). Relative deprivation and social justice: A study of attitudes to social inequality in 20th century England. London, United Kingdom: Routledge and Kegan Paul.

Scafuto, F., \& La Barbera, F. (2016). Protest against waste contamination in the 'land of fires': Psychological antecedents for activists and non-activists. Fournal of Community \& Applied Social Psychology, 26, 481-495. https://doi.org/10.1002/casp.2275

Shultziner, D., \& Kornblit, I. S. (2020). French Yellow Vests (Gilets faunes): Similarities and differences with occupy movements. Sociological Forum, 35, 535-542. https://doi.org/10.1111/socf.12593

Smith, H. J., Pettigrew, T. F., Pippin, G. M., \& Bialosiewicz, S. (2012). Relative deprivation: A theoretical and meta-analytic review. Personality and Social Psychology Review, 16, 203-232. https://doi.org/10.1177/1088868311430825

Somma, N. M., Bargsted, M., Disi Pavlic, R., \& Medel, R. M. (2021). No water in the oasis: The Chilean Spring of 2019-2020. Social Movement Studies, 20(4), 495-502. https://doi.org/10.1080/14742837.2020.1727737

Spruyt, B., Keppens, G., \& Van Droogenbroeck, F. (2016). Who supports populism and what attracts people to it? Political Research Quarterly, 69, 335-346. https://doi.org/10.1177/1065912916639138

Statista. (2018). Public opinion on France's “Yellow Vests” movement (Chart 16370). Retrieved from https://www.statista.com/chart/16370/public-opinion-france-yellow-vests-movement/

Urbanska, K., \& Guimond, S. (2018). Swaying to the extreme: Group relative deprivation predicts voting for an extreme right party in the French presidential election. International Review of Social Psychology, 31, Article 26. https://doi.org/10.5334/irsp.201

Urbanska, K., Pehrson, S., \& Guimond, S. (2021). Power to the people: Disidentification with the government and the support for populism. Journal of Theoretical Social Psychology, 5, 79-89. https://doi.org/10.1002/jts5.77

van den Bos, K. (2020). Unfairness and radicalization. Annual Review of Psychology, 71, 563-588. https://doi.org/10.1146/annurev-psych-010419-050953

van Zomeren, M., Spears, R., Fischer, A. H., \& Leach, C. W. (2004). Put your money where your mouth is! Explaining collective action tendencies through group-based anger and group efficacy. Journal of Personality and Social Psychology, 87, 649-664. https://doi.org/10.1037/0022-3514.87.5.649

Warren, P. (2020) Two concepts of populism. In M. Navin \& R. Nunan (Eds.), Democracy, populism, and truth (AMINTAPHIL: The Philosophical Foundations of Law and Justice, Vol. 9, pp. 21-34). Springer. https://doi.org/10.1007/978-3-030-43424-3_2

Wilkin, P. (2020). Fear of a Yellow planet: The Gilets Jaunes and the end of the modern world-system. Fournal of World-Systems Research, 26, 70-102. https://doi.org/10.5195/jwsr.2020.902

Zaslove, A., Geurkink, B., Jacobs, K., \& Akkerman, A. (2021). Power to the people? Populism, democracy, and political participation: A citizen's perspective. West European Politics, 44, 727-751. https://doi.org/10.1080/01402382.2020.1776490 